\title{
26. The Devonian Trilobites from the Fukuji and Other Formations in Japan
}

\author{
By Teiichi Kobayashi, M. J. A.
}

(Communicated May 12, 1988)

The age of the Fukuji Formation in Gifu Prefecture had been a subject of moot discussion until its early Devonian age was determined by the occurrence of Cheirurus (Crotalocephalus) japonicus Kobayashi and Igo, 1956. Before this a similar Favosites-bearing formation was found at Kiyomi, Gifu Prefecture and Oisedani, Fukui Prefecture (Ishioka and Kamei, 1950; Huzimoto et al., 1953). Now it is known that the formation overlies the Ordovician Yoshiki Formation in the west of Fukuji (Igo and Adachi, 1981).

The trilobites of these formations at Fukuji and Oise were later amplified with a new collection obtained at four localities, namely Kinmamichi, Kanajirozako, Ichinotani and Sorayama in the Fukuji district (Kobayashi and Hamada, 1977) and further by another collection from Sorayama. As the result the Fukuji fauna comprises now 21 species in total besides some exactly indeterminable ones as shown in the inserted list.

Among these 21 species in 15 genera of 7 families, namely the Scutelluidae, Proetidae, Otarionidae, Cheiruridae, Calymenidae, Odontopleuridae and Lichidae the leading family is the Cheiruridae comprising 9 species in 4 genera, followed by 6 species in 2 genera of the Proetidae. Lophiokephalion is a new genus founded on L. antijuva whose glabellar crest extending toward the eye whence an intragenal carina issues diagonally as seen in Dechenella. It is interesting to see such a phylogerontic specialization also in this new proetid.

Judging from Crotalocephalina, Pilletopeltis and Crotalocephalides the Fukuji fauna must be within the range from early Devonian to the beginning of the Eifelian age. This chronology is also in support of corals, brachiopods and other associates (Okazaki, 1974; Kuwano, 1984). At Sorayama Proetus (Coniproetus) fukujiensis occurs above and below the "Orthoceras" horizon and the vertical change of conodonts is also recognized through these strata (Kuwano, 1987). The Soradani faunule is the richest in the Fukuji fauna and Crotalocephalides sorayamensis, nov. indicates the faunal connection to Sardinia and east Thüringen, Germany through the Tethys Sea in the Pragium i.e. middle Lower Devonian age.

The Middle Devonian Formation of Hikoroichi, Sakari in the Kitakami mountains yields Scutellum (Thysanopeltella) paucispinosa Okubo and Phacops okanoi Okubo, 1985 in the lower part of the Nakazato Formation to which Kaneko (1984) added Acanthopyge (Acanthopyge) duplicispinosa, Nipponoarges mediosulcatus and Nipponocalymene hamadai besides dalmanitids, odontopleurids and others undescribed. Phacops (?) was found rarely in the lower part of the overlying Omori Formation. Recently Tazawa and Kaneko (1987) reported an occurrence of an Upper Devonian phacopid at Sangobata near Kamaishi in the so-called Hayachine tectonic belt in the Kitakami mountains.

The late Upper Devonian Tobigamori Formation in the Nagasaka District, Iwate Prefecture contains Cyrtispirifer yabei Noda and Tachibana, 1950 i.e. 
Table I. List of the Devonian trilobites of the Fukuji fauna

\begin{tabular}{|c|c|c|c|c|c|c|c|}
\hline & $I$ & & I & & & & II \\
\hline $\begin{array}{c}\text { Trilobites } \\
\text { of } \\
\text { Devonian Fukuji fauna }\end{array}$ & $\underset{\substack{5 \\
5}}{3}$ & 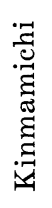 & 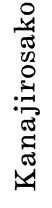 & 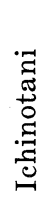 & 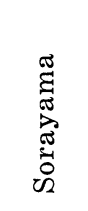 & 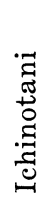 & $\stackrel{0}{0}$ \\
\hline $\begin{array}{l}\text { Scutelluidae } \\
\text { Hidascutellum multispiniferum } \\
\text { Microscutellum (?) densigranulatum } \\
\text { Scutelluid, gen. et sp. indet. }\end{array}$ & & $?$ & $\begin{array}{l}0 \\
0\end{array}$ & & $x$ & $X$ & $x$ \\
\hline $\begin{array}{l}\quad \text { Proetidae } \\
\text { Proetus (Coniproetus) fukujiensis } \\
\text { Lophiokephalion antijuba } \\
\text { Lophiokephalion longiconus } \\
\text { Lophiokephalion latipolus } \\
\text { Lophiokephalion angustus } \\
\text { Ungliproetus oisensis } \\
\text { Proetid, gen. et sp. indet. a } \\
\text { Proetid, gen. et sp. indet. b } \\
\text { Proetid, gen. et sp. indet. c }\end{array}$ & & & & $\begin{array}{l}0 \\
0\end{array}$ & $\begin{array}{l}0 \\
0 \\
0\end{array}$ & & $\times$ \\
\hline $\begin{array}{l}\text { Otarionidae } \\
\text { Otarion megalops }\end{array}$ & & & & & 0 & & \\
\hline $\begin{array}{l}\quad \text { Cheiruridae } \\
\text { Crotalocephalina aff. gibbus } \\
\text { Pilletopeltis japonicus } \\
\text { Pilletopeltis japonicus granulatus } \\
\text { Pilletopeltis kameii } \\
\text { Pilletopeltis apheles } \\
\text { Pilletopeltis apheles obtusus } \\
\text { Pilletopeltis (?) tetracantus } \\
\text { Crotalocephalides sorayamensis } \\
\text { Crotalocephalides sp. indet. } \\
\text { Crotalocephalides (?) sp. indet. } \\
\text { Geracephalina secta } \\
\text { Geracephalina secta projecta } \\
\text { Geracephalina convexa } \\
\text { Geracephalina euryrachis }\end{array}$ & 0 & $\begin{array}{l}0 \\
0\end{array}$ & $\begin{array}{l}0 \\
0 \\
0\end{array}$ & $\begin{array}{l}0 \\
0 \\
0\end{array}$ & $\begin{array}{l}0 \\
0 \\
0 \\
0\end{array}$ & & $\times$ \\
\hline $\begin{array}{l}\quad \text { Calymenidae } \\
\text { Gravicalymene yamakoshii } \\
\text { Gravicalymene cf. yamakoshii } \\
\text { Flexicalymenid, gen. et sp. indet. }\end{array}$ & & 0 & 0 & & 0 & & $\times$ \\
\hline $\begin{array}{l}\text { Lichidae } \\
\text { Craspedarges superbus } \mathrm{K} \text {. et } \mathrm{H} \text {. } \\
\text { Acanthopyge (Lobopyge ?) sp. indet. }\end{array}$ & & & & & $\begin{array}{l}0 \\
0\end{array}$ & & \\
\hline $\begin{array}{l}\quad \text { Odontopleuridae } \\
\text { Primaspis (?) tanakai K. et } \mathrm{H} \text {. } \\
\text { Ceratocephala nipponica K. et } \mathrm{H} \text {. }\end{array}$ & & & 0 & & 0 & & \\
\hline
\end{tabular}

See Kobayashi and Igo, 1956, Kobayashi and Hamada, 1977 and Kobayashi, in print, for I, II and III respectively. 
Spirifer verneuili by Yabe, 1933 and some other fossils including Leptophloem which occurs also in the Ochi Formation near Ochi, Kochi Prefecture, Shikoku Island, but no trilobite is associated at these localities (Hirata, 1966a, b).

In looking over these Devonian trilobite localities the Fukuji fauna at Fukuji and Oise in the Hida plateau is so rich that it consists of 21 species, 14 genera and 7 families in which Lophiokephalion is a sole indigenous genus. The Middle Devonian trilobites of Hikoroichi may attain some ten species when undescribed ones are added. Thus the species-number is reduced to less than a half of the Fukuji fauna, while there appear two new genera. This difference suggests that endemism was emphasized from the early to the middle Devonian age. Late Devonian phacopids from Sangobata and in the Omori Formation are rare relics in Japan. Finally no trilobite is contained in the late Upper Devonian Tobigamori fauna.

\section{References}

Fujimoto (Huzimoto), H., Kanuma, M., and Midorikawa, Y. (1953) : Gotlandian deposits newly discovered from Kiyomi-mura, Gifu Prefecture. Studies Geol. Min. Inst. Tokyo Univ. Educ., no. 2, pp. 11-16.

Igo, H., and Adachi, S. (1981) : Study on the Palaeozoic rocks in the Fukuji District, Kamitakara Village, Yoshiki County, Gifu Prefecture-Present status and unsolved problems. J. Geogr. Tokyo, $90(5), 336-345$.

Ishioka, I., and Kamei, T. (1970): Discovery of Gotlandian Formation in the upper part of Kuzuryu River, Fukui Prefecture (preliminary report). J. Geol. Soc. Japan, 56, 57-58.

Kaneko, A. (1985) : A Middle Devonian trilobite fauna from the Kitakami Mountains, northeast Japan-1. The Lichidae, 2. The Calymenidae. Trans. Proc. Palaeont. Soc. Japan, N. S., no. 136 , pp. $473-491$, pls. $87-89$; no. 138 , pp. $94-98$.

Kobayashi, T., and Hamada, T. (1974) : On the geological age of the Fukuji Formation in the Hida Plateau. Proc. Japan Acad., 50, 760-763.

- (1977a): Outline of Devonian trilobites in Japan. ibid., 53, 147-150.

- (1977b) : Devonian trilobites of Japan in comparison with the Asian, Pacific and other faunas. Palaeont. Soc. Japan, Sp. Pap., no. 20, 201 pp., 13 pls.

Kobayashi, T., and Igo, H. (1956) : Discovery of Crotalocephalus, Devonian trilobite in Hida, West Japan. Japan. J. Geol. Geogr., 27 (2-4), 143-155.

Kuwano, Y. (1986) : Geological age of the Fukuji Formation, Central Japan. Mem. Nat. Sc. Mus. Tokyo, 19, 67-70.

Okazaki, Y. (1974): Devonian trilobites from Fukuji Formation in the Hida Massif, Central Japan. Mem. Kyoto Univ. Sc. Geol. Min., 40(2), 83-94, 9 pìs.

Okazaki, Y., Tanaka, K., and Tanaka (1974): A discovery of the Devonian trilobites from Fukuji Prefecture. J. Geol. Soc. Japan, 80(11), 563, pl. 1.

Tazawa, J., and Kaneko, A. (1987): Discovery of a Devonian trilobite from the Eastern part of the Hayachine tectonic belt, Kitakami Mountains, Northeast Japan. ChikyuKagaku, $41(1)$, 65-68. 